\title{
IMPACT OF CONTINUOUS ICT TRAINING IN SECONDARY SCHOOL TEACHERS IN PORTUGAL
}

\author{
Ruí-Felipe Bernardo Costa \\ Antonio Campos Sánchez \\ Alfonso Conde Lacárcel \\ Juan Antonio Lopez Núñez \\ Antonio Moreno Ortiz \\ Tomás Sola Martínez
}

Universidad de Granada /Facultad de Ciencias de la Educación / Didactics and School Organization Department/Campus de Cartuja, Spain

\begin{abstract}
This paper focuses on the relevance of Continuous Teacher Training in the development of the required skills for effectively and efficiently employing Information and Communication Technologies in the secondary school classroom, as a set of not only useful, but necessary resources in today's teaching context. Research was conducted on secondary school teachers in the Municipality of Coimbra (Portugal), with a view to survey the teacher's perception on a number of related issues.
\end{abstract}

Keywords: Continuous Teacher Training, ICT training, Secondary Education

\section{Introduction}

Continuous Teacher Training (CTT), as defined by the Lei de Bases do SistemaEducativoPortuguês (Basic Law of the Portuguese Educational System), developed in 1986 and institutionalized in 1992, has not always been understood by its mainactors, i.e., teachers, as a resourceaimed at improving the conditions of the teaching/learning process as a whole. Facing a career where advancement depended not only on length of service, but to a large extent on the acquisition of "credit units", teachers suspected that the requirement to follow training activities would only be one more hurdle to prevent career advancement.

Many institutions showed interest in offering and developing CTT activities: school associations, unions, and higher education institutions 
(Caballero and Levis, 2007). Both training professionals and programmes had to be certified prior to the training services being actually offered to the teaching community. On the other hand, teachers being pressed to take part in CTT activities resulted in their hastily and poorly guided search for such training, which was reduced to choosing from simple lists of courses offered whose main description was the number obtained, which would measure their training progression (Cabero, Llorente, and Gisbert, 2007).

In these circumstances, the offer was linked to the demand (Campos and Körner, 2005), that is, training institutions offered what they could and trainees chose used their own criteria to make a choice, both sides seriously limited by the lack of knowledge and information that the training institutions offered regarding the real needs of trainees (Caetano, 2003).

Many years after the institutionalization of CTT, the situation still remains confusing, bringing into question the quality of the training and the objectives to be achieved by the training process (Ramos, 2005). On the one hand, there is a generalized awareness among the teaching community regarding the need for training, not simply based on "credit hunting", and, on the other, teachers now display some sort of adaptation to the new system of career progression (Tejedor and Valcarcel, 2006). This adaptation allows not only for some early planning of the "how" and "when" to attend this or that training action, but also means that, within flexible time constraints, teachers can seek training topics or areas more suited to their profile and needs from training institutions (Souza, 2005).

It was in this context that training in the area of Information and Communication Technologies developed. Great importance was given to the use of technological tools to meet the needs of contemporary society in general and, in particular, to their potential as teaching and learning tools (Cañellas, 2006; Gonçalves, 2002).

This issue is discussed by a number ofscholars, such as Gomez (1993), Hokanson and Hooper (2004), who states that one of the research areas to be developed within the relationship between educational actions and the use of technology is to develop taxonomies of applications with specification of their objectives, sectors and educational levels.

The Portuguese Ministry of Education, aware of this new reality, began to legislate on this issue and to give guidance regarding the importance and use of ICT in schools (Decree-Law nr. 6/2001 of 18 January - Ratified in accordance with Statement of Ratification nr. 4-A/2001, published in the DR (Official Gazette), I-A, nr. 50, of 28 February 2001 and Amended by Decree-Law nr. 209/2002, of 17 October). By 2007training in ICT was properly regulated CRIE/DGIDC/ME/2007, (Continuous teacher training Reference Chart in the area of ICT). 
In 2008, the Education Technology Plan was launched. This plan aimed to organize training programmes within the school, according to their specific needs, aiming to strengthen the school's autonomy and capacity for action, as an implementation of the educational policy on public education (Law nr. 75/2008, of 22 April).

It is within this context that we pose the main topic of our research, which could be very roughly summarized in the following questions: what do teachers think of their training in ICT? What is their perception regarding its use in the teaching/learning process? How do they use the ICT in their teaching?

\section{Methodology}

\section{Research objectives}

Specifically, we aim to address the following issues:

1) Analyse the relationship between academic and continuous training and the needs related to teaching duties.

2) Assess the use of ICT in the activities of secondary school teachers of the Municipality of Coimbra.

3) Evaluate the effective application of ICT in the educational context of secondary schools of the Municipality of Coimbra, in the different dimensions of the teaching-learning process.

4) Assess the potential of ICT as a tool and resource to be used in the school context in question.

We thus intended to inquire about the nature and quality of teacher training and thus be able to verify if the education was gained through the initial training, continuous training, or both. Moreover, we verified what teachers thought about the quality of their own training. We also wanted to know what perception teachers have regarding the potential of these new tools, by establishing a relationship between their perceptions and the use of these tools in their teaching duties.

Given the above, this research aims to contribute to the improvement of the development and the quality of the teaching-learning process, based on adequate use of ICT as a tool to be used by the educational community.

\section{Population and sample}

The population of our study comprises all the teachers in the secondary schools of the Municipality of Coimbra. The choice of the city of Coimbra was due to the fact that it is a medium-sized city, with many schools, located in the centre of Portugal, and, we believe, fairly representative of the country.

To this end, we made a request to GEPE (Office of Statistics and Education Planning), the entity responsible for ensuring the educational 
production and statistical analysis, for the data regarding the number of teachers effectively working in these schools. We verified that the population consisted of 757 teachers, distributed among different curricular departments.

Aware that a significant proportion of this population would not respond to our questionnaire and that the sample would have to be representative, we used the technique of simple random sampling for finite populations, applying the mathematical formula proposed by R. Sierra Bravo (1988), N = n G2 ( $*$ * Q) / E2 ( -1$)+\mathrm{G} 2(\mathrm{P} * \mathrm{Q})$. Thus, we concluded that the sample should consist of at least 266 respondents, about $35 \%$ of the population.

\section{Instruments and methodology}

A questionnaire was selected as the most appropriate instrument for collecting quantitative information in this context (Hill and Hill, 2008; Trujillo, Lopez and Lorenzo, 2011) Its construction underwent several stages, which were supervised by one of the six groups of teachers specifically invited to comment on it. We also put together a focus group with the aim of obtaining ideas and questions for the design of the questionnaire. Suggestions emanating from the various players in the construction of the questionnaire were progressively reformulated until its form and content responded to these suggestions, as well as to the objectives of our research.

Before its final implementation, implemented a pilot study in the Secondary School of Cantanhede, in the district of Coimbra. The reasons to choose this school were twofold: it has a relatively large teaching population (100 teachers), and it is located relatively close to the schools where the questionnaire would be applied. We emailed all teachers in this school requesting collaboration in our study and sent them the questionnaire, with instructions on how to complete it. In all, 35 teachers responded to the request, none of who pointed out misinterpretations of any of the items, or raised any other issues.

This pilot study reassured us that the instrument was adequate to our purpose, so the next step involved dealing with certain legal issues imposed by Portuguese law, which demands that requires that the research instruments be approved by GEPE (Office of Statistics and Education Planning). The final version of the questionnaire consisted of 43 questions grouped in four sections:

Section 1: items 1-6 on biographical data;

Section 2: items 7-16 on ICT training;

Section 3: items 17-31 on the perception of the use of ICT in the context of teaching and learning; 
Section 4: items32-43 on the use of ICT in the classroom.

After GEPE approved the questionnaire, we developed a website developed, supported by PHP and MySQL technologies, which enabled the creation of a user-friendly interface. The site was online for a month (from May 15 to June 15, 2009). The result was 391 acceptable responses.

To assess the reliability of our sample, we used Cronbach's Alpha, as implemented in SPSS v17.0, which was applied to items 7 to 43 (those quantitative in nature). We obtained an index 0.805 , which means that the internal consistency in our data was very high.

As for the focus group, it consisted mostly of teachers with a similar amount of experience on the issue in question and similar professional background (Perremoud, 2001; Serrâo 2007; Taylor 2004). For the group to achieve maximum effectiveness, we decided to communicate in two different ways: a monthly group meeting and individual and group emailing and instant messaging. The former offered the advantage of being more direct and formal where all issues were discussed, while the latter proved to be extremely effective in dealing with minor issues that came up during the study.

Six group meetings were scheduled, with a maximum duration of two hours. As a starting point, we set out to discuss a number of aspects of the quantitative study, the type of instruments used, the defined population, the sample produced and the analysis of results and conclusions to be achieved. Finally, we agreed that the observations, comments or conclusions to be submitted should be made in a unified final document to be referred to as "Considerations of the Focus Group".

\section{Results and Discussion}

SPSS v.17 and Microsoft Office Excel 2003 where used to analyse the data. The contingency tables that follow attempt to summarize our most relevant results.

\section{Section 1: Bio data}

\begin{tabular}{|c|c|c|c|c|c|}
\hline \multicolumn{2}{|c|}{ Q1 } \\
\hline \multirow{2}{*}{} & Frequency & Percentage & $\begin{array}{c}\text { Valid } \\
\text { Percentage }\end{array}$ & $\begin{array}{c}\text { Cumulative } \\
\text { Percentage }\end{array}$ \\
\hline \multirow{3}{*}{ Valid } & Female & 232 & 59,3 & 59,3 & 59,3 \\
\cline { 2 - 6 } & Male & 159 & 40,7 & 40,7 & 100,0 \\
\cline { 2 - 6 } & Total & 391 & 100,0 & 100,0 & \\
\hline
\end{tabular}

Table 1: Item 1 - Gender 


\begin{tabular}{|c|c|c|c|c|c|}
\hline \multicolumn{2}{|c|}{ Q2 } \\
\hline \multirow{7}{*}{} & Frequency & Percentage & $\begin{array}{c}\text { Valid } \\
\text { Percentage }\end{array}$ & $\begin{array}{c}\text { Cumulative } \\
\text { Percentage }\end{array}$ \\
\hline \multirow{7}{*}{ Valid } & $26-30$ & 13 & 3,3 & 3,3 & 3,3 \\
\cline { 2 - 6 } & $31-35$ & 46 & 11,8 & 11,8 & 15,1 \\
\cline { 2 - 6 } & $36-40$ & 51 & 13,0 & 13,0 & 28,1 \\
\cline { 2 - 7 } & $41-45$ & 70 & 17,9 & 17,9 & 46,0 \\
\cline { 2 - 7 } & $46-50$ & 113 & 28,9 & 28,9 & 74,9 \\
\cline { 2 - 7 } & $51-55$ & 65 & 16,6 & 16,6 & 91,6 \\
\cline { 2 - 7 } & $56-60$ & 20 & 5,1 & 5,1 & 96,7 \\
\cline { 2 - 7 } & $61-65$ & 13 & 3,3 & 3,3 & 100,0 \\
\cline { 2 - 7 } & Total & 391 & 100,0 & 100,0 & \\
\hline
\end{tabular}

Table 2: Item 2 -Age

The sample has individuals with ages between 26 and 65 years, most notably in the range [46-50], which corresponds to $28.9 \%$ of the sample, which is nonetheless indicative of a significant percentage with a vast experience in teaching, possibly justified by the privileged geographical area of the selected sample.

\begin{tabular}{|c|c|c|c|c|c|}
\hline \multicolumn{2}{|c|}{} & Frequency & Percentage & $\begin{array}{c}\text { Valid } \\
\text { Percentage }\end{array}$ & $\begin{array}{c}\text { Cumulative } \\
\text { Percentage }\end{array}$ \\
\hline \multirow{7}{*}{ Valid } & $\begin{array}{c}\text { Bachelor's } \\
\text { (a five year } \\
\text { course) }\end{array}$ & 18 & 4,6 & 4,6 & 4,6 \\
\cline { 2 - 6 } & \begin{tabular}{c} 
Megree \\
\cline { 2 - 6 }
\end{tabular} & 330 & 84,4 & 84,4 & 89,0 \\
\cline { 2 - 6 } & Toter's & 43 & 11,0 & 11,0 & 100,0 \\
\hline
\end{tabular}

Table 3: Item 3: Academic Degree

The sample consists of individuals with different academic degrees. The percentage of teachers with a Master's degree (11\%) should be highlighted, as it may indicate awareness of the importance of professional development. In contrast, the percentage of BA degrees (4.6\%) seems rather significant, which appears to be somewhat odd in relation to their professional development, when considering the educational reforms that have taken place over the last years and which allowed teachers with a 
Bachelor's degree to integrate the School Boards, in response to the needs of the Educational System of the time.

\begin{tabular}{|c|c|c|c|c|c|}
\hline \multicolumn{2}{|c|}{ Q4 } \\
\hline \multirow{7}{*}{} & Frequency & Percentage & $\begin{array}{c}\text { Valid } \\
\text { Percentage }\end{array}$ & $\begin{array}{c}\text { Cumulative } \\
\text { Percentage }\end{array}$ \\
\hline \multirow{7yyyyy}{*}{ Valid } & $0-5$ & 28 & 7,2 & 7,2 & 7,2 \\
\cline { 2 - 6 } & $6-10$ & 30 & 7,7 & 7,7 & 14,8 \\
\cline { 2 - 6 } & $11-15$ & 53 & 13,6 & 13,6 & 28,4 \\
\cline { 2 - 6 } & $16-20$ & 49 & 12,5 & 12,5 & 40,9 \\
\cline { 2 - 6 } & $21-25$ & 101 & 25,8 & 25,8 & 66,8 \\
\cline { 2 - 6 } & $26-30$ & 66 & 16,9 & 16,9 & 83,6 \\
\cline { 2 - 6 } & $31-35$ & 51 & 13,0 & 13,0 & 96,7 \\
\cline { 2 - 6 } & $36-40$ & 13 & 3,3 & 3,3 & 100,0 \\
\cline { 2 - 6 } & Total & 391 & 100,0 & 100,0 & \\
\hline
\end{tabular}

Table 4: Item 4 - Service time

This shows that our participants have differentiated service time, varying between 0 and 40 years. We highlight the range [21-25], which represents $25.8 \%$ of the sample, which is nonetheless indicative of a significant proportion of individuals with extensive teaching experience, which confirms the possible reasons already presented in the statistical analysis of Item 2 .

\begin{tabular}{|c|c|c|c|c|c|}
\hline \multicolumn{6}{|c|}{ Q5 } \\
\hline & & Frequency & Percentage & $\begin{array}{c}\text { Valid } \\
\text { Percentage }\end{array}$ & $\begin{array}{l}\text { Cumulative } \\
\text { Percentage }\end{array}$ \\
\hline \multirow{5}{*}{ Valid } & $\begin{array}{l}\text { Social and } \\
\text { Human } \\
\text { Sciences }\end{array}$ & 73 & 18,7 & 18,7 & 18,7 \\
\hline & Expressions & 39 & 10,0 & 10,0 & 28,6 \\
\hline & Languages & 89 & 22,8 & 22,8 & 51,4 \\
\hline & $\begin{array}{l}\text { Mathematics } \\
\text { and } \\
\text { Experimental } \\
\text { Sciences }\end{array}$ & 190 & 48,6 & 48,6 & 100,0 \\
\hline & Total & 391 & 100,0 & 100,0 & \\
\hline
\end{tabular}

Table 5: Item 5 - Curricular Department 
Our sample is therefore distributed over four curricular departments, most notably the Mathematics and Experimental Sciences that has 48.6\%, representing almost half of the sample under study. It is noteworthy that in most schools, particularly in our school population, 320 teachers integrate the curricular department of Mathematics and Experimental Sciences, which in turn has an impact on the representativeness of the answers obtained.3.2 Sections 2-4. ICT specific

\begin{tabular}{|c|c|c|c|c|c|}
\hline \multicolumn{2}{|c|}{} & Frequency & Percentage & $\begin{array}{c}\text { Valid } \\
\text { Percentage }\end{array}$ & $\begin{array}{c}\text { Cumulative } \\
\text { Percentage }\end{array}$ \\
\hline \multirow{7}{*}{ Valid } & Initial & 58 & 14,8 & 14,8 & 14,8 \\
\cline { 2 - 6 } & Continuous & 210 & 53,7 & 53,7 & 68,5 \\
\cline { 2 - 6 } & Both & 46 & 11,8 & 11,8 & 80,3 \\
\cline { 2 - 6 } & Neither & 77 & 19,7 & 19,7 & 100,0 \\
\cline { 2 - 6 } & Total & 391 & 100,0 & 100,0 & \\
\hline
\end{tabular}

Table 6.Item 6 - Training in ICT

The sample shows varying levels of training in ICT. Reference should be made to the fact that $19.7 \%$ had no training in ICT whatsoever, which reveals significant disinterest or inability to access this type of training. The statistical analysis regarding Items 1 (gender), 2 (age), and 4 (service time) should be emphasized, as they lead to the assumption, with the proper precautions, that the sample consists mostly of middle-aged female teachers with significant service time, thus subject to the technology shock of the twenty-first century, lacking skills, and having insensitivity and resistance to the field of ICT. 


\section{Correlation 1}

Item 6: Training in ICT Item 32: In planning lessons, makes privileged use of ICT as a way to better address the contents.

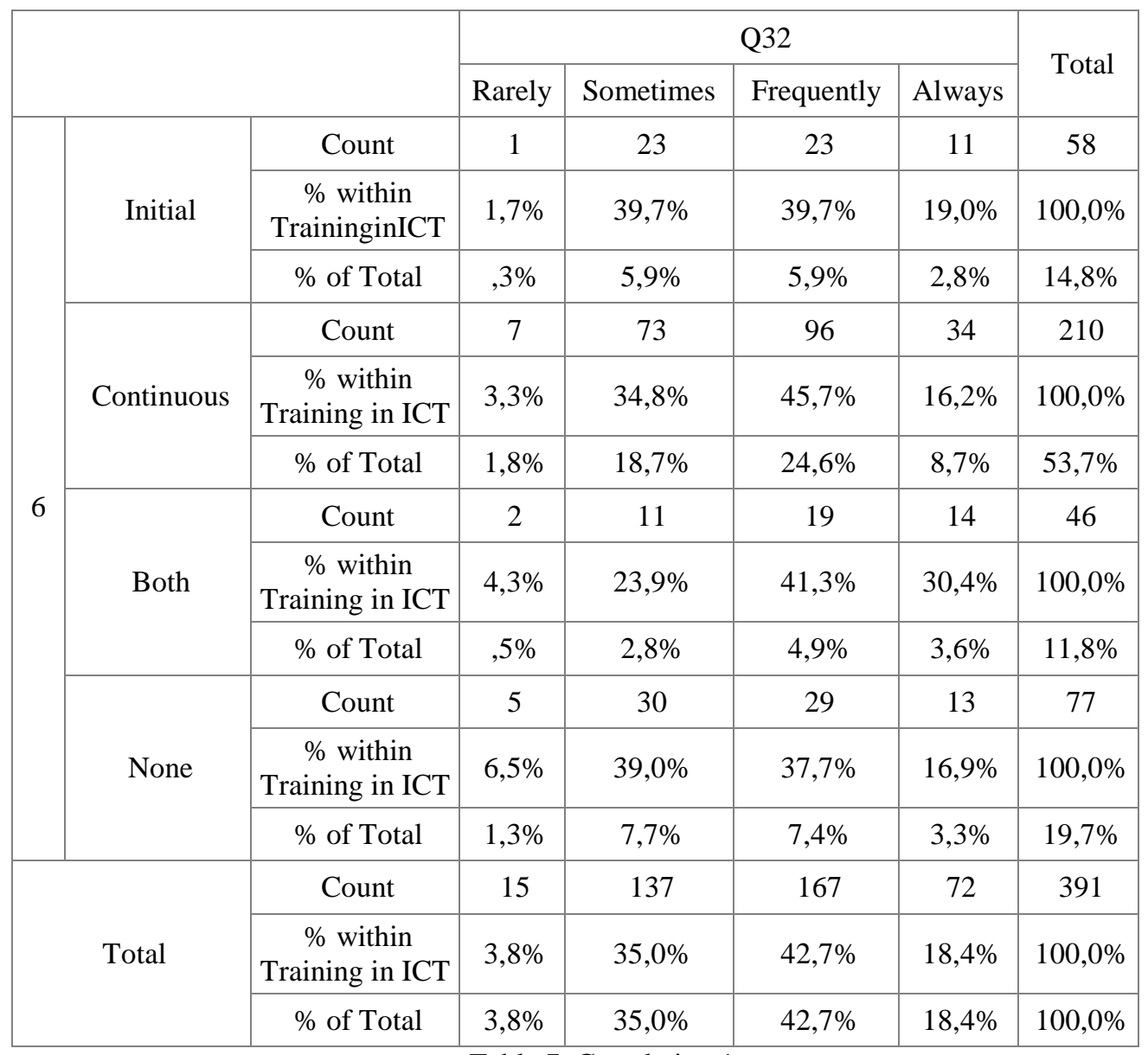

Table 7. Correlation 1

The data show that, in planning their lessons, the respondents favor the use of new technologies as a way to better address the contents. The chisquare test of independence presents a value of 19.914 and a significance of 0.035 , which leads us to conclude that there, is dependence between the type of training and the answer given by respondents. 


\section{Correlation 2}

Item 6: Training in ICT

Item 33: Uses ICT for creating innovative and diverse strategies

\begin{tabular}{|c|c|c|c|c|c|c|c|}
\hline & \multicolumn{4}{|c|}{ Q33 } & \multirow{2}{*}{ Total } \\
\hline & & & Rarely & Sometimes & Frequently & Always & \\
\hline \multirow{12}{*}{6} & \multirow{3}{*}{ Initial } & Count & 1 & 22 & 22 & 13 & 58 \\
\hline & & \% within Training in ICT & $1,7 \%$ & $37,9 \%$ & $37,9 \%$ & $22,4 \%$ & $100,0 \%$ \\
\hline & & $\%$ of Total & ,3\% & $5,6 \%$ & $5,6 \%$ & $3,3 \%$ & $14,8 \%$ \\
\hline & \multirow{3}{*}{ Continuous } & Count & 8 & 93 & 77 & 32 & 210 \\
\hline & & \% within Training in ICT & $3,8 \%$ & $44,3 \%$ & $36,7 \%$ & $15,2 \%$ & $100,0 \%$ \\
\hline & & $\%$ of Total & $2,0 \%$ & $23,8 \%$ & $19,7 \%$ & $8,2 \%$ & $53,7 \%$ \\
\hline & \multirow{3}{*}{ Both } & Count & 1 & 19 & 21 & 5 & 46 \\
\hline & & \% within Training in ICT & $2,2 \%$ & $41,3 \%$ & $45,7 \%$ & $10,9 \%$ & $100,0 \%$ \\
\hline & & $\%$ of Total & ,3\% & $4,9 \%$ & $5,4 \%$ & $1,3 \%$ & $11,8 \%$ \\
\hline & \multirow{3}{*}{ None } & Count & 5 & 38 & 28 & 6 & 77 \\
\hline & & \% within Training in ICT & $6,5 \%$ & $49,4 \%$ & $36,4 \%$ & $7,8 \%$ & $100,0 \%$ \\
\hline & & $\%$ of Total & $1,3 \%$ & $9,7 \%$ & $7,2 \%$ & $1,5 \%$ & $19,7 \%$ \\
\hline & \multirow{3}{*}{ Total } & Count & 15 & 172 & 148 & 56 & 391 \\
\hline & & \% within Training in ICT & $3,8 \%$ & $44,0 \%$ & $37,9 \%$ & $14,3 \%$ & $100,0 \%$ \\
\hline & & $\%$ of Total & $3,8 \%$ & $44,0 \%$ & $37,9 \%$ & $14,3 \%$ & $100,0 \%$ \\
\hline
\end{tabular}

Table 8. Correlation 2

Respondents are using new technologies to create innovative and diversified strategies. The chi-square test of independence presents a value of 19.802 and a significance of 0.036 , which leads us to conclude that there is dependence between the type of training and the answer given by respondents. 


\section{Correlation 3}

Item 6: Training in ICT Item 34: Takes advantage of the vast potential of ICT for the production of teaching materials

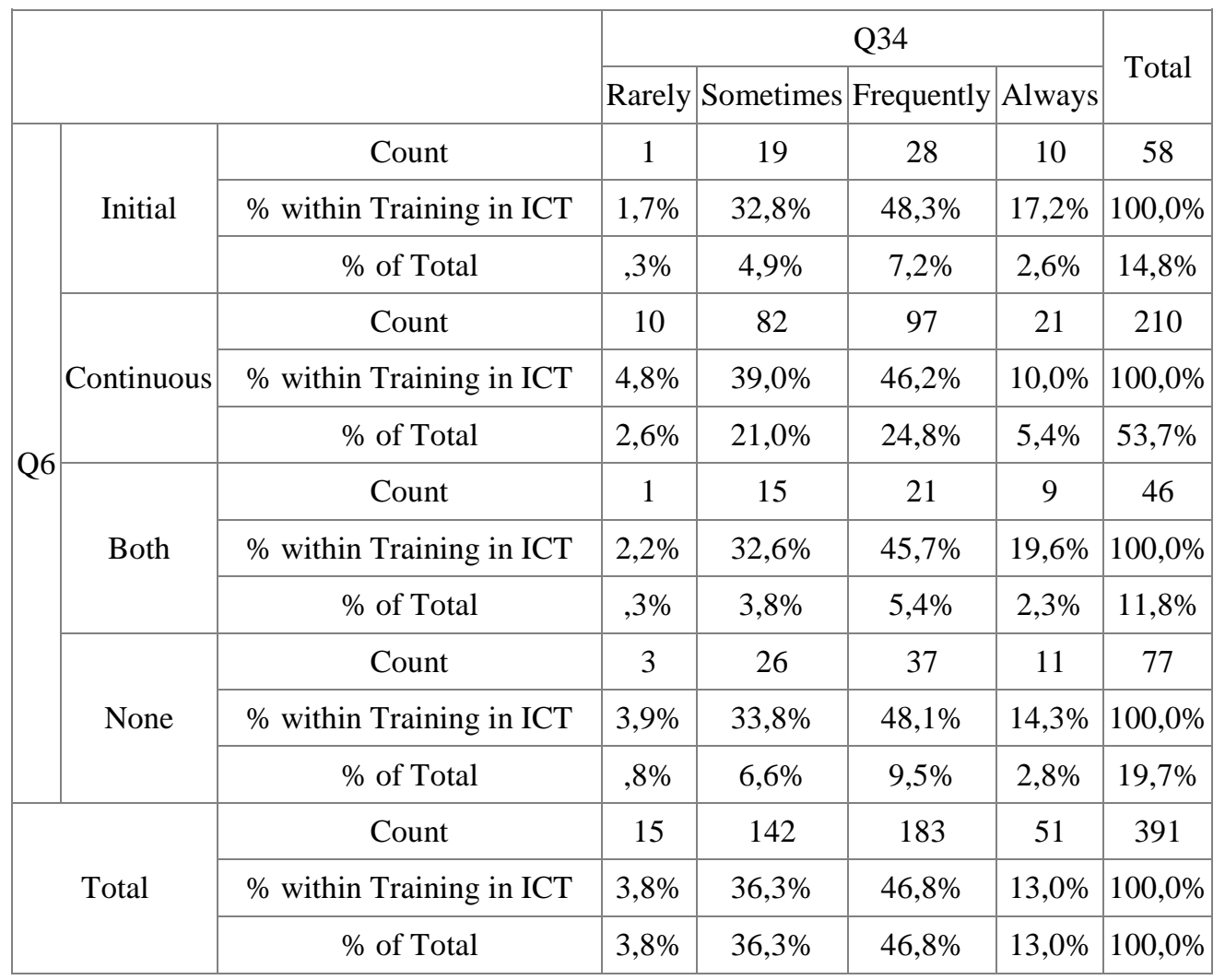

Table 9. Correlation 3

This should be taken as evidence that respondents do take advantage of the vast potential of ICT for the production of teaching materials. The chisquare test of independence presents a value of 17.369 and a significance of 0.070 , which leads us to conclude that there is dependence between the type of training and the answer given by respondents.3.2.4 Correlation 4 


\section{Correlation 4}

Item 6: Training in ICT

Item 35: Makes use of ICT for the development of educational projects

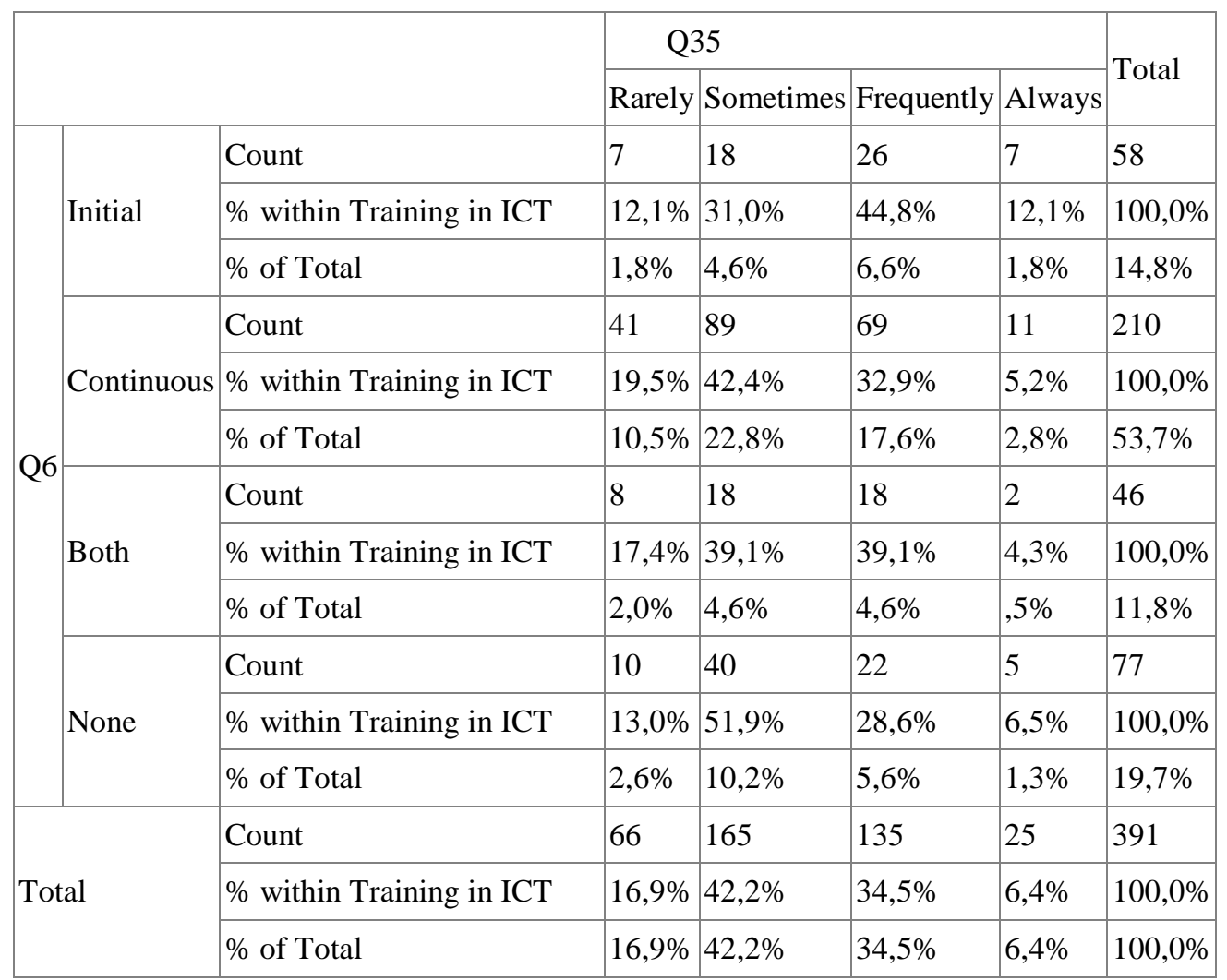

Table 10. Correlation 4

This contingency table provides evidence to the fact that respondents make use of ICT for the development of educational projects. The chi-square test of independence presents a value of 12.603 and a significance of 0.181 , which leads us to conclude that there is no dependence between the type of training and the answer given by respondents. 


\section{Correlation 5}

Item 6: Training in ICT Item 36: Creates conditions for students to use ICT as a space of discovery and discussion of different topics

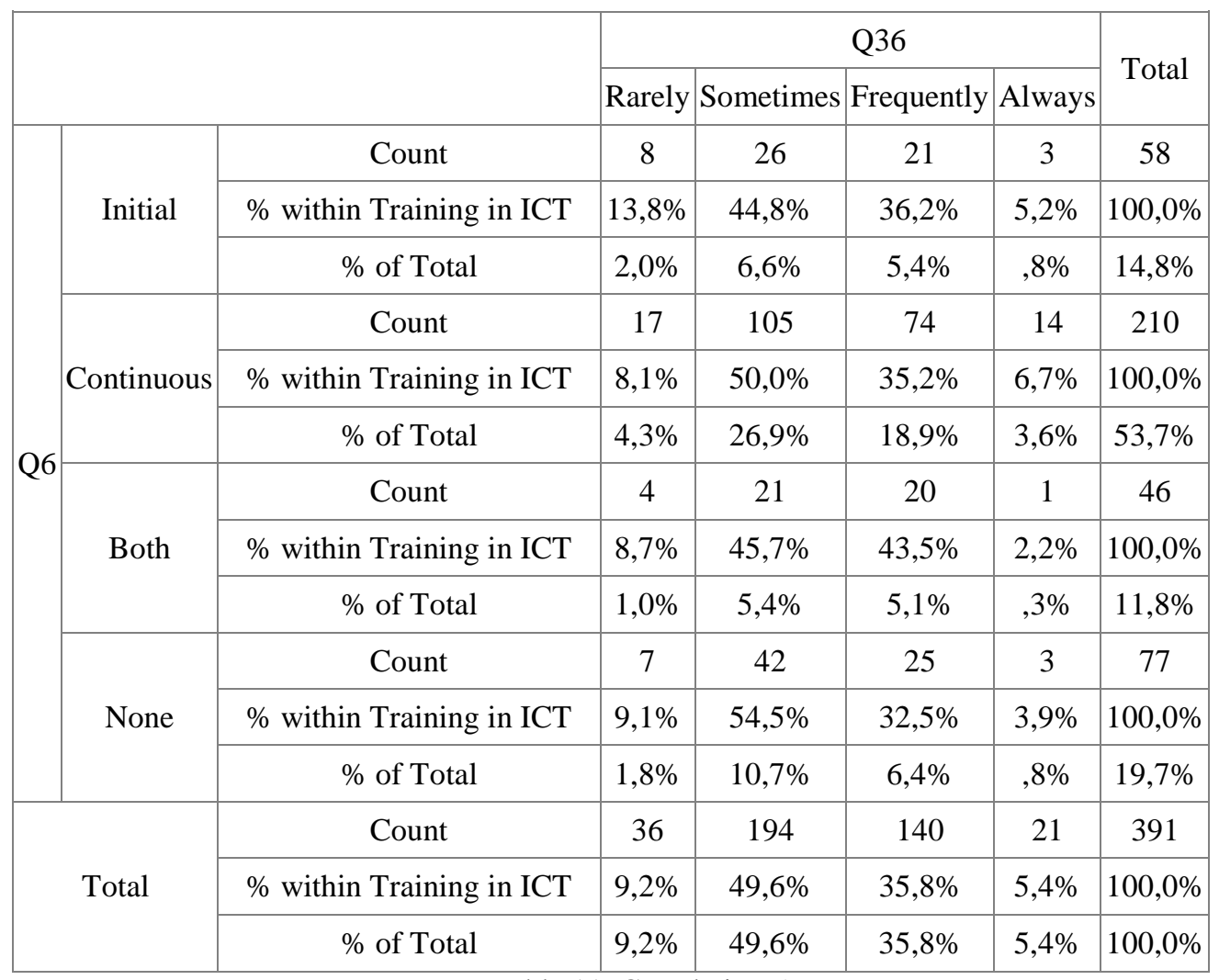

Table 11. Correlation 5

Analysing the contingency table, we find that respondents created conditions for students to use ICT as a space of discovery and discussion of different topics. The chi-square test of independence presents a value of 5.283 and a significance of 0.809 , which leads us to conclude that there may be no dependence between the type of training and the answer given by respondents. 


\section{Correlation 6}

Item 6: Training in ICT Item 37: Uses the new technology as a way to increase students' interest and motivation

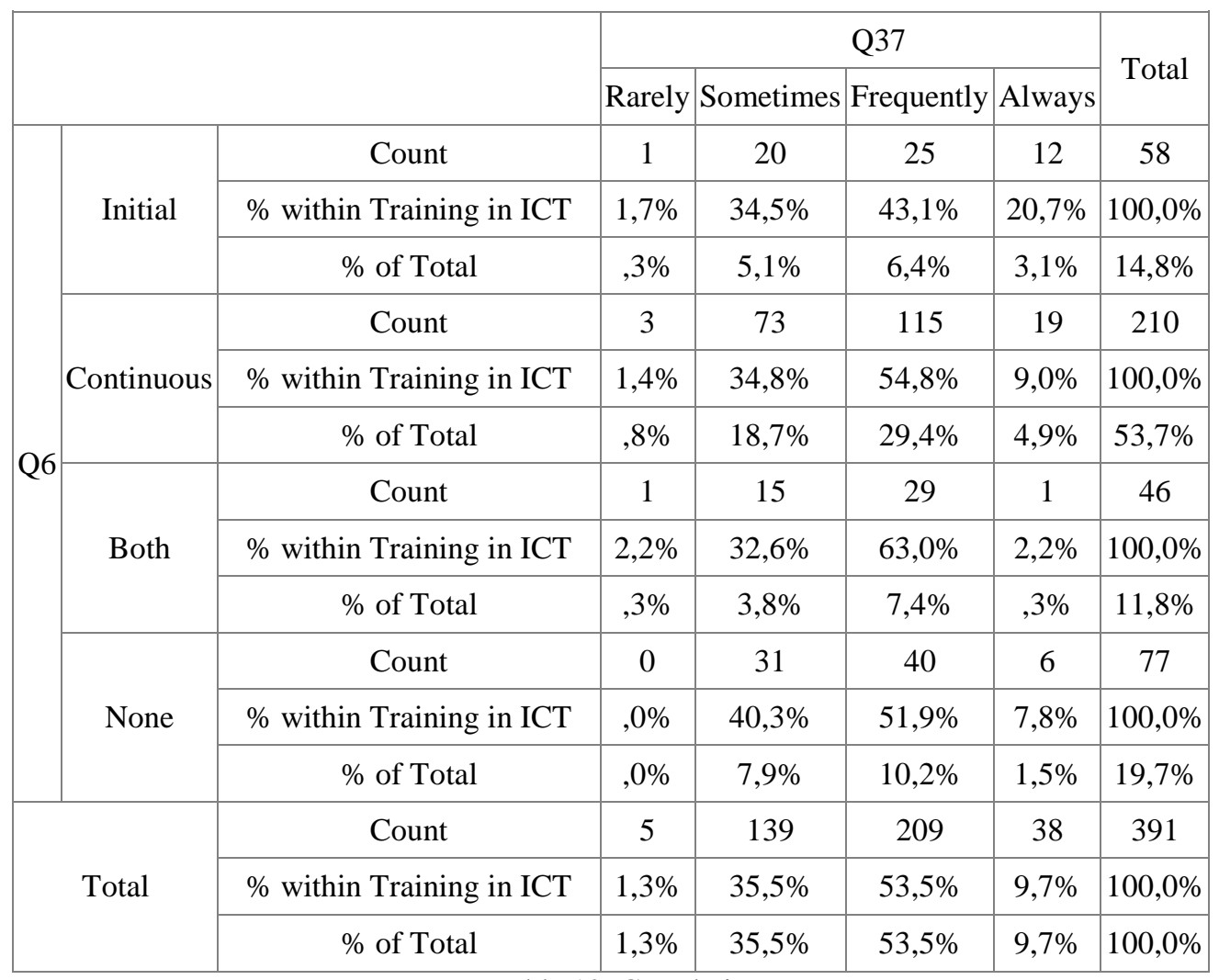

Table 12. Correlation 6

The data here point to the fact that respondents use new technologies as a way to increase students' interest and motivation. The chi-square test of independence presents a value of 17.370 and a significance of 0.011 , which leads us to conclude that there, is dependence between the type of training and the answer given by respondents. 


\section{Correlation 7}

Item 6: Training in ICT students

Item 38: Uses ICT to attempt to change individual attitudes of

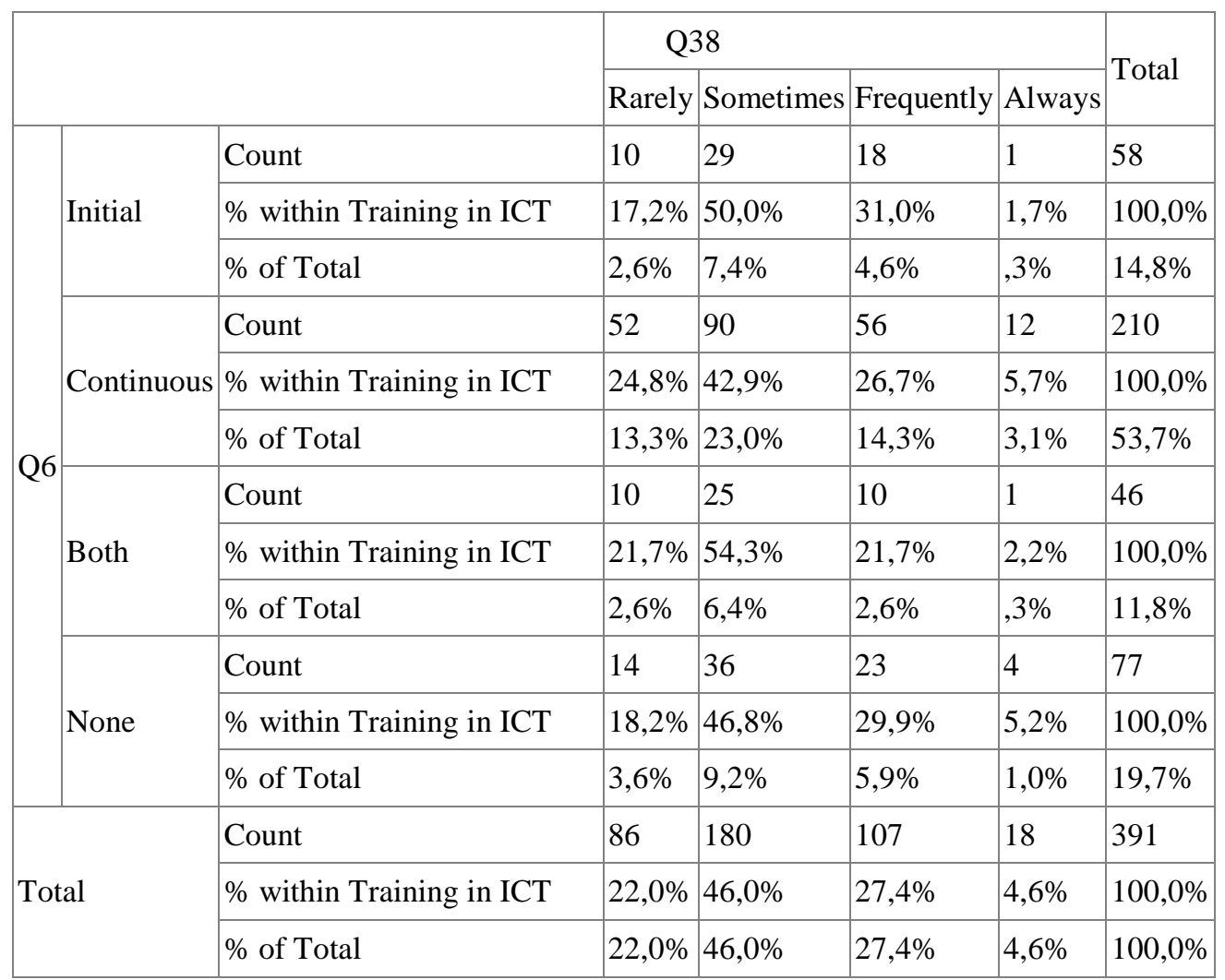

Table 13. Correlation 7

The data seem to provide evidence that respondents do in fact use ICT to be able to modify individual attitudes of students. The chi-square test of independence presents a value of 16.482 and a significance of 0.691 , which leads us to conclude that there may be no dependence between the type of training and the answer given by respondents. 


\section{Correlation 8}

Item 6: Training in ICT Item 39: Encourages the use of ICT to develop students' autonomy

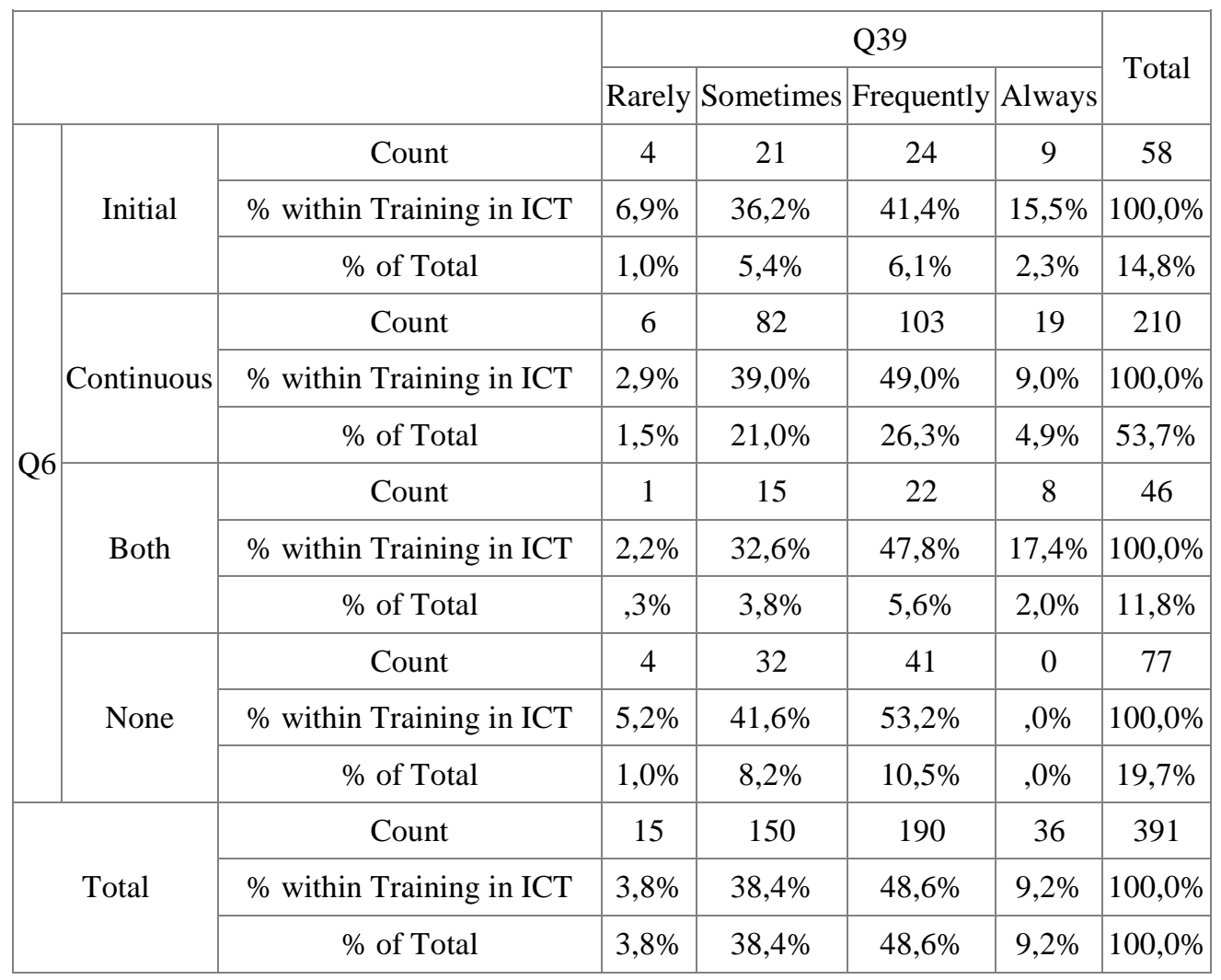

Table 14. Correlation 8

Analysis of this contingency table reveals that respondents encourage the use of ICT to develop students' procedures for autonomy. The chi-square test of independence presents a value of 17.269 and a significance of 0.045 , which leads us to conclude that there, is dependence between the type of training and the answer given by respondents. 


\section{Correlation 9}

Item 6: Training in ICT Item 40: Promotes the development of extra activities for collaborative or group work

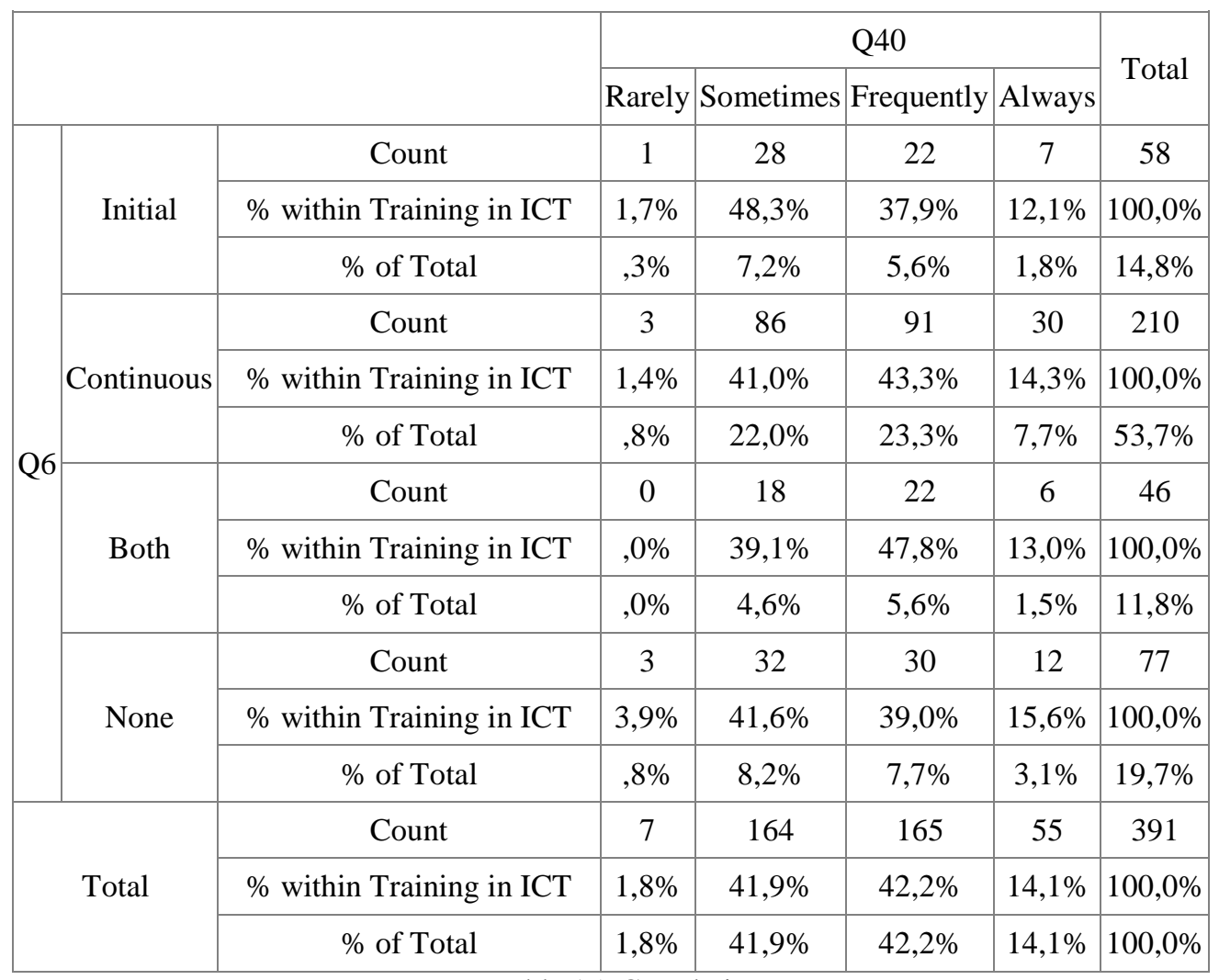

Table 15. Correlation 9

The data here point to the fact that respondents do promote the development of extra activities to develop collaborative or group work. The chi-square test of independence presents a value of 17.762 and a significance of 0.085 , which leads us to conclude that there, is dependence between the type of training and the answer given by respondents. 


\section{Correlation 10}

Item 6: Training in ICT Item 41: Using ICT to overcome difficulties arising from the development of the lesson

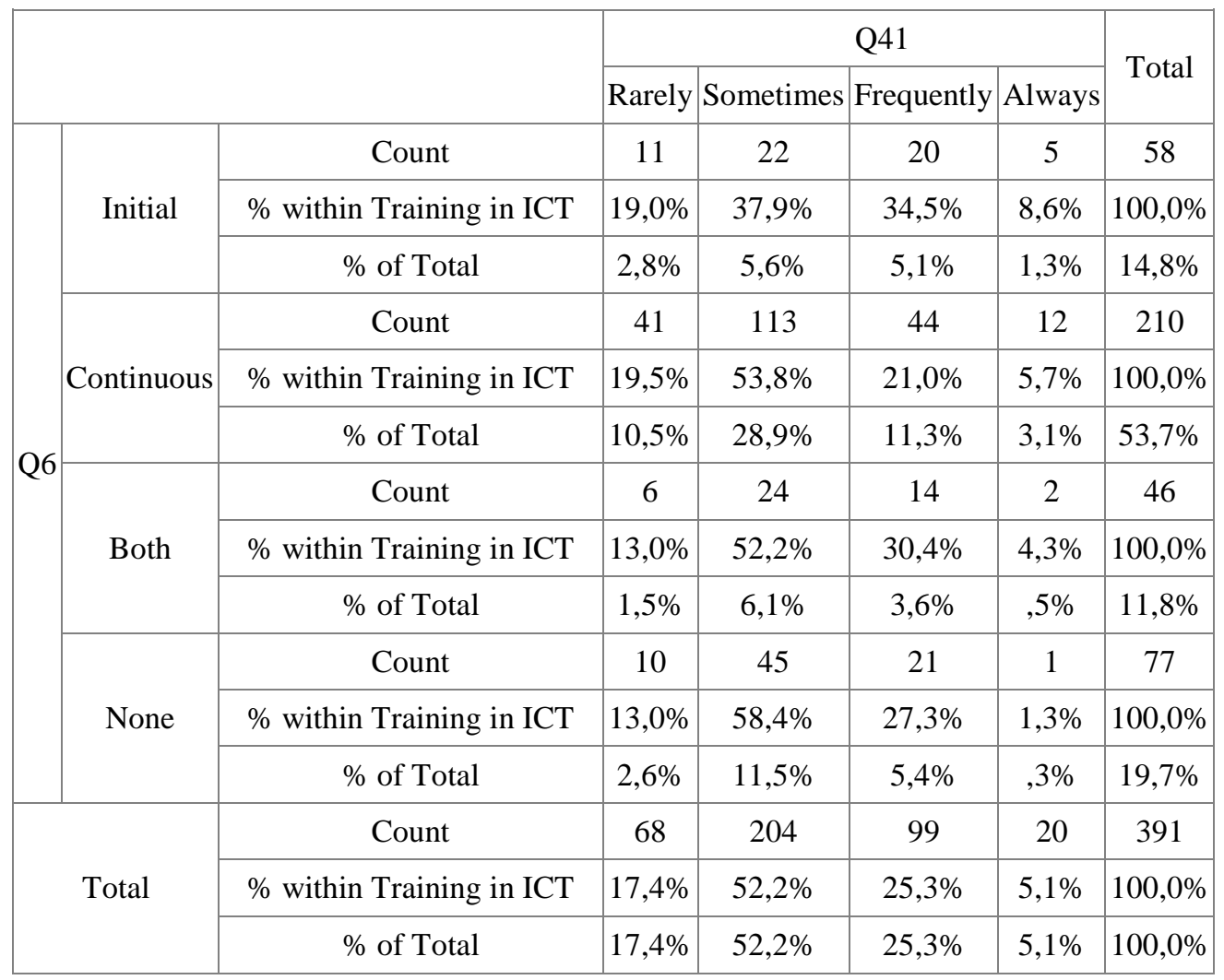

Table 16. Correlation 10

Analysing the contingency table, we find that respondents rely upon the ICT to overcome difficulties arising from the development of the lesson. The chi-square test of independence presents a value of 18.816 and a significance of 0.017 , which leads us to conclude that there, is dependence between the type of training and the response given by respondents. 


\section{Correlation 11}

Item 6:Training in ICT Item 42: Uses new technology to share work generated by students

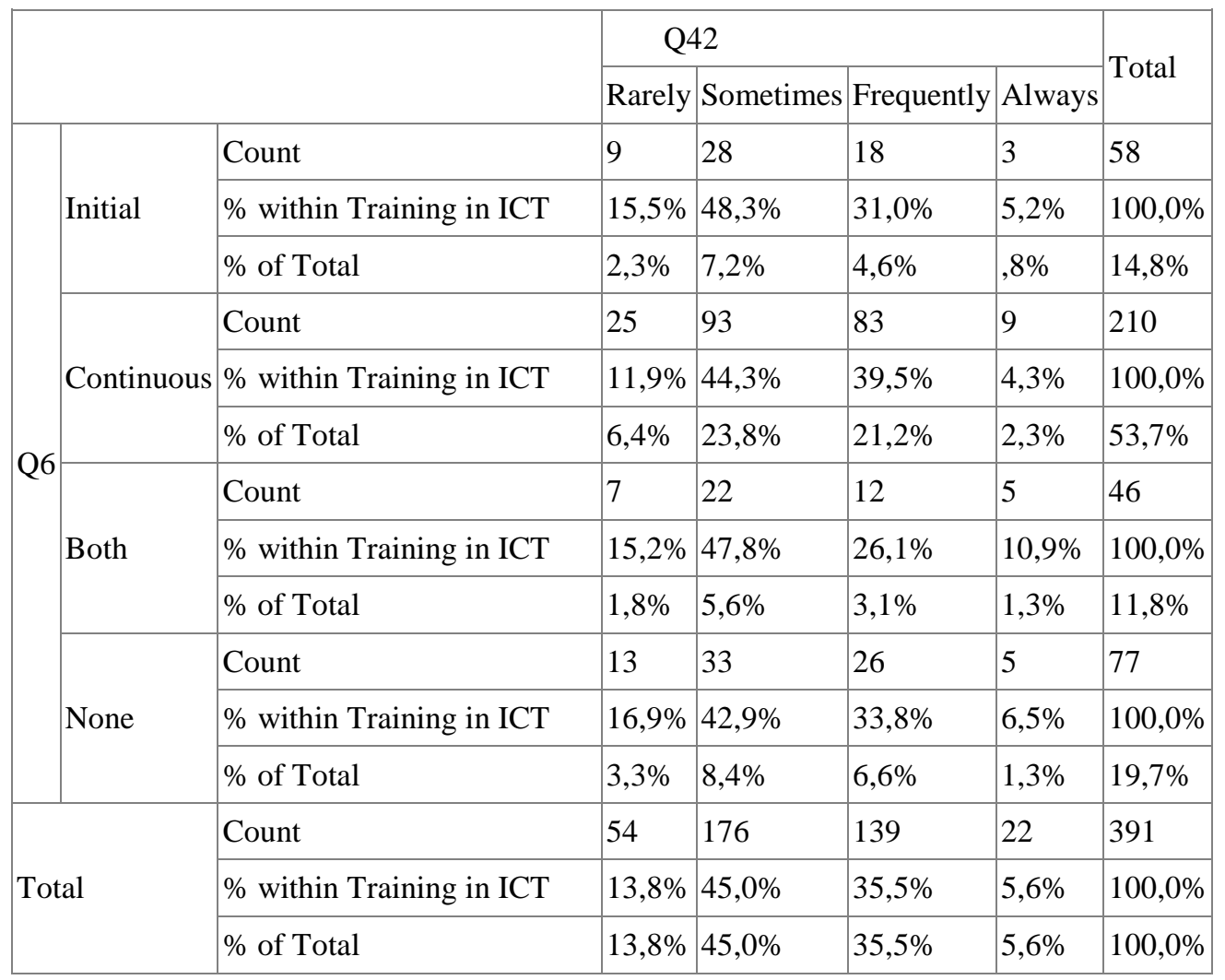

Table 17. Correlation 11

Respondents do seem to use ICT to share work generated by students. The chi-square test of independence presents a value of 17.125 and a significance of 0.006, which leads us to conclude that there, is dependence between the type of training and the answer given by respondents. 


\section{Correlation 12}

Item 6:Training in ICT Item 43: Disseminates assignments, activities, or projects using ICT

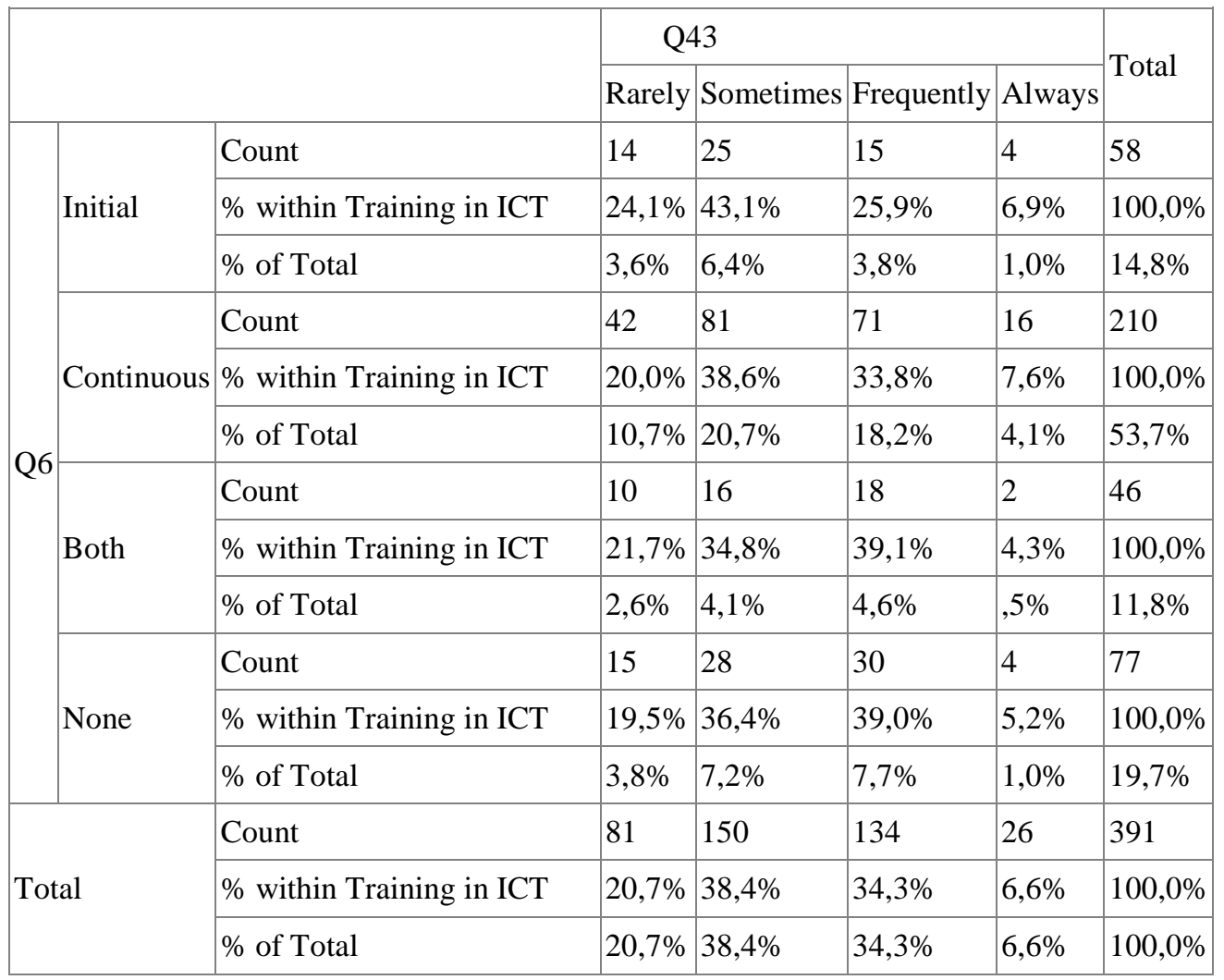

Table 18. Correlation 12

Analysing the contingency table, we find that the respondents engaged in dissemination of assignments, activities or projects, using new technologies. The chi-square test of independence presents a value of 17.970 and a significance of 0.091 , which leads us to conclude that there is dependence between the type of training and the answer given by respondents.

\section{Factorial Analysis}

For this study we used SPSS V.17 to develop a variability matrix (descriptive), the estimation of common factors and specific factors (extraction), and the rotation of factors (rotation). We also used SPSS to estimate factor values (scores).

Before performing the analytical process, it was necessary to establish whether the data met the necessary conditions to make the 
application of the methodology of factor analysis possible. Using SPSS we verified whether the conditions for the applicability of the test were present, in this case by means of the Kaiser-Meyer-Olkin and Bartlett's test of Sphericity.

For this purpose we considered only the following items: I8, I9, I10, I12, I14, I18, I20, I21, I22, I23, I24, I25, I27, I28, I30, I32, I33, I35, I36, I37, I38, I39, I41, I42 and I43, which we believed to be the most significant.

The result we obtained for the KMO measure was 0.805 , which we considered valid, given that the benchmark should be above 0.60 . We also noted a significance value of 0.000 through Bartlett's test, which is less than 0.05 , allowing us to conclude that the correlation matrix is an identity matrix.

In light of these results, we proceeded to the application of factor analysis and obtained the symmetric correlation matrix. Once the number of factors was calculated and the issues grouped, we moved on to their classification and definition by an equal number of categories, which were given the following designation and consequential reasoning:

Innovation category: Items 27, 33, 36, and 41 show a clear intention to use ICT as an innovative and more effective means in addressing the different situations of teaching and learning.

Communication category: Items 21, 28, 23, 30 focus essentially on communicative contexts in the different types of inter-relationships: teachers, students, school, family, etc.

Collaboration category. Items 39 and 25 covered the use of ICT in a collaborative approach and its practical application in connecting the school with the community.

Relationships category. Items 24 and 22 was directed at the relationship student/student, teacher/student and others emerging from relational contexts provided by these special means of information and communication.

Valorisation category. Items 2, 4, and 9 referred to the professional development of teachers through continuous training, taking their needs into account.

Motivation category. Items 38and 37 aimed to increase interest and motivation of students as well as the changing of behaviour of individuals or of group/class.

Planning category. Items 32, 10, 35, and18 meant preparing a suitable plan for the achievement of the objectives that the teacher aimed to reach, namely regarding the best way to approach the contents.

Assessment category. Items 8 and20 lead us to a comprehensive assessment of the quality of the teacher training process as well as the implementation of new resources to improve students' performance. 


\section{Conclusion}

From the analysis of the collected data, we found that the reception and the willingness of respondents towards the use of ICT were substantial, irrespective of the type of training that they held. Although there have been extensive programmes of continuous training in ICT and many institutions providing them, these programmes rarely go beyond the perspective of the common user. This finding could lead us to conclude that this factor could contribute to the relegation of the introduction of ICT in educational settings. However, this has not happened, and the respondents indicated that they significantly use ICT in their teaching activities and consider the salient role that these resources can play the context of teaching and learning. However, we would like to point out that there is still a lot to do in this field, particularly regarding the current framework for training, given that there is a certain gap between the technological knowledge and the specific areas to which it is addressed. Respondents considered essential that a specific type of training should be designed for each subject area, with its own methodology.

We also found that the type of training received by respondents is not a limiting factor in the use of ICT in an educational context. However, the way in which it is used, limits their practice. This fact indicates that there is an urgent need to include strategies for the development of skills and competencies in the school curriculum to allow for the maximization of the use of ICT in various areas.

We would also like to emphasize that it is equally important to promote critical awareness for a teaching context guided by collaboration, interactivity, and dynamism, based on the actual awareness of the need to articulate the curricula and make them flexible. In this sense, in accord with the views of Pablos (2007) and Cardoso (2002), we believe that in the society of information and knowledge in which we live, it is essential to reflect on the concept of teaching and learning in the diverse contexts in which they are performed, as well as on ways of improving them.

In short, we believe that continuous teacher training is of crucial importance, especially in regard to ICT, given that in the development of this process there is a renewed effort, with implications regarding the training programmes, the status of the profession, the change of schools, and the social prestige of teachers.

\section{Funding}

This research received no specific grant from any funding agency in the public, commercial, or nonprofit sectors. 


\section{References:}

Cabello, R. \& Levis, D. (2007). Medios informáticos en la educación a principios del siglo XXI. Buenos Aires: Editorial Prometeo.

Cabero, J., Llorente, M. \& Gisbert, M. (2007). El papel del profesor y el alumno en los nuevos entornos tecnológicos de formación. En J. Cabero, Nuevas tecnologías aplicadas a la educación (pp. 120-135).Madrid: Mcgraw-Hill.

Caetano, A. (2003). Os processos participativos e investigativos na mudança dos professores e da escola. Lisboa: Ministério da Educação.

Campos, R. \& Körner, A. (2005). Nuevas tecnologías y formación docente: análisis de experiencias relevantes en América Latina. Chile: Orealc/Unesco.

Cañellas, A. (2006). Impacto de las TIC en la educación: un acercamiento desde el punto de vista de las funciones de la educación. Quaderns Digitals: Revista de Nuevas Tecnologías y Sociedad, n. 43, 45-60.

Cardoso, A. (2002). A receptividade à mudança e à inovação pedagógica: o professor e o contexto escolar. Porto: Edições ASA.

Gómez, V. (1993). El profesor del futuro y las nuevas tecnologías. Murcia: Universidad Complutense de Madrid.

Gonçalves, Z. (2002). A mudança da organização educativa por integração dasTecnologias de Informação e Comunicação na Educação (TICE): Um estudo de casosobre as implicações da integração das TIC na escola. Dissertação de doutoramento.Braga: Universidade do Minho.

Hill, m. \& Hill A. (2008). Investigação por questionário. Lisboa: Edições Sílabo.

Hokanson, b. \& Hooper, S. (2004). Integrating Technology in Classrooms: We Have Met the Enemy and He is Us. Association for Educational Communications and Technology. ERIC, ED485143.

Pablos, J. (2007). El cambio metodológico en el espacio europeo de educación superior y el papel de las tecnologías de la información y la comunicación. Revista Iberoamericana de Educación a Distancia, v. 10, (2), 123-145.

Perrenoud, P. (2001). Dez Medidas Para Tornar O Sistema Educativo Mais Eficaz. Lisboa: Edições Asa.

Tejedor, J. \& Valcárcel, A. (2006). Competencias de los profesores para el uso de las TIC en la enseñanza. Análisis de sus conocimientos y actitudes. Revista Española de Pedagogía, n. 233, 120-142.

Ramos, J. (2005). Experiências educativas enriquecedoras no âmbito das Tecnologias de Informação e Comunicação em Portugal. En R. Silva \& A. Silva (Orgs.), Educação, aprendizagem e tecnologia: um paradigma para professores do século XXI. Lisboa: Edições Sílabo.

Serrão, C. (2007). Programação em PHP 5. Lisboa: Lidel. 
Sierra, R. (1988). Técnicas de Investigación Social. Teoría y Ejercicios. Madrid: Paraninfo.

Souza, R. (2005). Uma proposta construtivista para a utilização de Tecnologias naEducação. En R. Silva \& A. Silva (Org), Educação, aprendizagem e tecnologias: um paradigma para professores do século XXI. Lisboa: EdiçõesSílabo.

Taylor, L. (2004). How student teachers develop their understanding of teaching using ICT.Journal of Education for Teaching, n. 30, 65-83.

Trujillo, J. M., López, J. A. \& Lorenzo, M. E. (2011). Análisis y Descripción de las Percepciones del Liderazgo Resiliente y Liderazgo Distribuido en Torno al Ejercicio Directivo (Web 2.0) como Posibilidad para Aprehender y Transformar las Instituciones Educativas. REICE. Revista Iberoamericana sobre Calidad, Eficacia y Cambio en Educación, 9 (3), 13-29. http://www.rinace.net/reice/numeros/arts/vol9num3/art1.pdf. Consultado el $(15 / 01 / 2013)$.

\section{Legislation}

Declaração de Rectificação n. 4-A/2001, de 28 de Fevereiro.

Decreto-Lei n. 6/2001, de 18 de Janeiro.

Decreto-Lei n. ${ }^{\circ}$ 209/2002, de 17 de Outubro.

Decreto-Lei n. 75/2008, de 22 de Abril.

Despacho n. 206/ME/85, de 15 de Novembro.

Despacho n. 232/ME/1996, do Diário da República n. 251, II Série, de 4/10.

Diário da República, $1^{\text {a }}$ série - n. 180 - 18, de Setembro de 2007. 